\title{
The Meanings of Drowning in Military-Themed Art: Analyzing a Sample of Random Civilizations and Timeframes through History
}

\author{
Stathis Avramidis* and Stavros Patrinos
}

Hellenic Centre for Disease Control and Prevention Greece

\begin{abstract}
Introduction: Artists have depicted drowning episodes in drawings with a religious, mythological, historical, suicidal, homicidal and military context. We aimed to identify the messages that the paintings with a drowning scene during a military/combat situation deliver to viewers. Method: A criterion sampling method identified paintings that portray drowning episodes during military and combat situations $(n=57)$. Chi-squared tests were used for comparison between categorical variables. Results: Ten statistically significant differences were identified between the bystanders at the time of occurrence $(\mathrm{p}=0.046)$, the bystanders by the depiction of military weapons $(\mathrm{p}=0.010)$, the bystanders by the number of casualties $(p=0.049)$, the bystanders by the drowning stage of the casualty $(p=0.014)$, the location by the means of transportation $(\mathrm{p}<0.001)$, the location by the drowning stage $(\mathrm{p}<0.001)$, the water depth during the rescue attempt $(\mathrm{p}=0.012)$, the water depth at the time of transportation $(\mathrm{p}<0.001)$, the casualty characteristics by the use of military weapons $(\mathrm{p}=0.001)$ and finally the casualty number by the means of transportation $(\mathrm{p}=0.018)$. Conclusions: Casualties were portrayed to be most often military adult males that drowned at sea in deep water. They were often seen to be immersed carrying weapons, and were witnessed by the bystanders. Art has provided us with a heritage of depictions that portrays drowning during military or combat situations. Warriors were always depicted accurately drowning but not always swimming. From this wealth of artistic information, we can deduce how the portrayed warriors and/or civilians under distress met their end or survived a drowning episode and avoided the enemy.
\end{abstract}

Keywords: Art, combat, battle, drowning, military, painting, rescue, swimming, war.

\section{INTRODUCTION}

Artists have depicted drowning episodes in drawings with a variety of themes, but no study has been conducted yet to identify what messages they present to their viewers. Specifically, a number of scholarly works and conference presentations have been dedicated recently to show how art has depicted swimming and/or drowning in paintings with a religious, mythological, historical, suicidal, homicidal and military content [1-8]. All these studies and presentations have revealed what previous studies have neglected to demonstrate and also underestimated the value of such studies from a scientific point of view. However, they approached the subject in a superficial descriptive way without arriving at any valid conclusions. On the other hand, no study had yet been conducted to specifically identify any "hidden" messages that military themed art presents to the viewer. In others words, no study so far has answered the question "what does art tell us about drowning at the battlefield?" Therefore, the aim of the present study was to identify any potential messages that the paintings with a military-drowning theme deliver to their viewers.

*Address correspondence to this author at the Nekrotafeio Kouvara, PO Box 30015, PC 19001, Kouvaras, Greece; Tel: +30-22990-68552;

E-mail: elagreece@gmail.com

\section{METHOD}

Using a criterion sampling method [9], we identified a number of paintings $(\mathrm{n}=57)$ that depicted a drowning incident during a military or combat situation. This search was undertaken utilizing internet web search engine machines, museums, academic libraries, as well as history and art books. After the paintings had been collected, a visual observation enabled the identification and the establishment of common variables that provoked an interest enough to be researched. Specifically, these variables were clustered in four categories that previous research has identified as crucial for understanding the drowning process (i.e., the rescuer and casualty characteristics, the place and the circumstances of occurrence of the drowning episode; [10]). Frequencies were computed and chi-squared tests were used for comparison between categorical variables. Significance tests were two-sided. P-values of 0.05 or less were considered statistically significant. Analysis was performed using STATA v12.1 software. In addition, some issues that could not be included in this statistical analysis were evaluated qualitatively.

\section{RESULTS}

Table 1, depicts the frequencies of the variables that were identified in the paintings that depicted drowning incidents during military and combat situations. 
Table 1. Frequencies of the Variables that were Identified in the Paintings that Depicted Drowning Incidents During Military and Combat Situations $(\mathbf{n}=\mathbf{5 7})$.

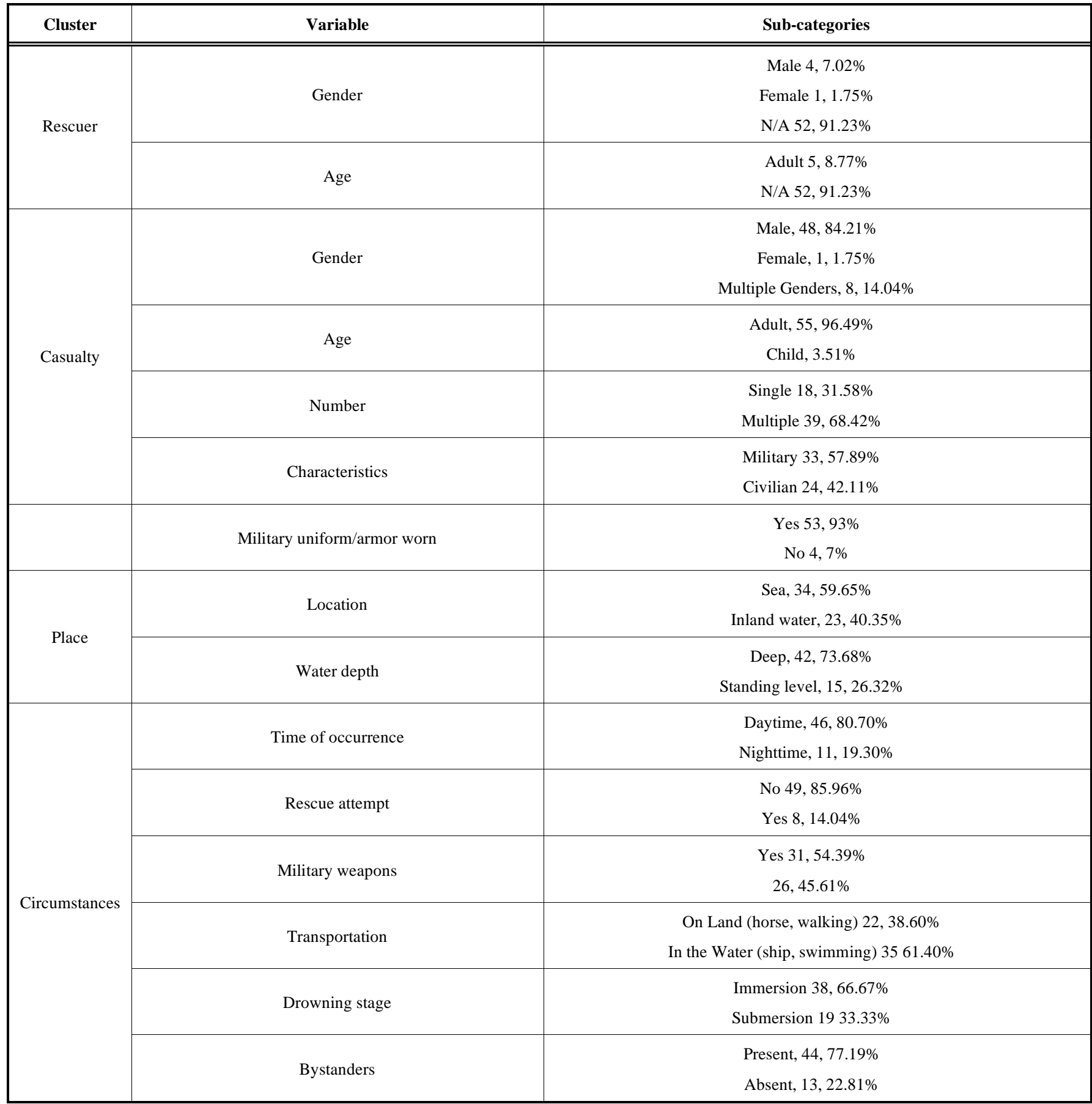

In Table 2, a statistically significant difference was noted between the bystander presence and the time of drowning $(\mathrm{p}=0.046)$. Specifically, during the day time $(38,82.61 \%)$ it was more likely to have a bystander presence than during the night $(8,17.39 \%)$. On the other hand, during the night the frequencies were almost equal $(50 \pm 5 \%)$.

In Table 3, a statistically significant difference was noted between the bystander presence and the use of military weapons $(p=0.010)$. Specifically, when there were bystanders present at the drowning episode the military weapons were more often carried by the warriors (28,
$90.32 \%)$. On the other hand, in the absence of bystanders the paintings did not portray any military weapons in the military themes that contained a drowning episode (10, $38.46 \%)$.

In Table 4, a statistically significant difference was noted between the bystander presence and the number of casualties occurred due to drowning $(p=0.049)$. Specifically, in the presence of bystanders the casualties caused by drowning were more often multiple $(33,84.62 \%)$. On the other hand, in the absence of bystanders people drowned on their own $(7,38.89 \%)$. 
Table 2. Bystander Presence by the Time of Occurrence of a Drowning Episode that was Depicted in Paintings with a Military or Combat Theme.

\begin{tabular}{|c|c|c|c|}
\hline \multirow{2}{*}{ Bystanders } & \multicolumn{3}{|c|}{ Time } \\
\cline { 2 - 4 } & Day & Night & Total \\
\hline \hline Yes & 38 & 6 & 74 \\
\hline$\%$ & 82.61 & 54.55 & 13 \\
\hline No & 8 & 5 & 22.81 \\
\hline Total & 17.39 & 45.45 & 57 \\
\hline
\end{tabular}

Note. Pearson chi-square $=3.9710, \operatorname{Pr}=0.046$.

Table 3. Bystander Presence by the Use of Military Weapons that was Depicted in Paintings with a military or Combat Theme.

\begin{tabular}{|c|c|c|c|}
\hline \multirow{2}{*}{ Bystanders } & \multicolumn{3}{|c|}{ Depiction of Military Weapons } \\
\cline { 2 - 4 } & Yes & No & 44 \\
\hline \hline Yes & 28 & 16 & 77.19 \\
\hline$\%$ & 90.32 & 61.54 & 13 \\
\hline No & 3 & 38.46 & 22.81 \\
\hline Total & 9.68 & 26 & 57 \\
\hline$\%$ & 31 & 100.00 & 100.00 \\
\hline
\end{tabular}

Note. Pearson chi-square $=6.6546, \operatorname{Pr}=0.010$.

Table 4. Bystander Presence by the Number of Casualties During a Drowning Episode that was Depicted in Paintings with a Military or Combat Theme.

\begin{tabular}{|c|c|c|c|}
\hline \multirow{2}{*}{ Bystanders } & \multicolumn{3}{|c|}{ Casualty Number } \\
\cline { 2 - 4 } & One & Multiple & 44 \\
\hline \hline Yes & 11 & 33 & 77.19 \\
\hline$\%$ & 61.11 & 84.62 & 13 \\
\hline No & 7 & 6 & 22.81 \\
\hline$\%$ & 38.89 & 39 & 57 \\
\hline Total & 18 & 100.00 & 100.00 \\
\hline
\end{tabular}

Note. Pearson chi-square $=3.8646, \operatorname{Pr}=0.049$. 
Table 5. Bystander Presence by the Stages of a Drowning Episode that was Depicted in Paintings with a Military or Combat Theme[

\begin{tabular}{|c|c|c|c|}
\hline \multirow{2}{*}{ Bystanders } & \multicolumn{3}{|c|}{ Drowning Stage } \\
\cline { 2 - 4 } & Immersion & Submersion & Total \\
\hline \hline Yes & 33 & 11 & 74.19 \\
\hline$\%$ & 86.84 & 57.89 & 13 \\
\hline No & 5 & 8 & 22.81 \\
\hline Total & 13.16 & 19 & 57 \\
\hline$\%$ & 38 & 100.00 & 100.00 \\
\hline
\end{tabular}

Note. Pearson chi-square $=6.0288, \operatorname{Pr}=0.014$.

Table 6. Location by the Transportation Means that was Used During a Drowning Episode that was Depicted in Paintings with a Military or Combat Theme]

\begin{tabular}{|c|c|c|c|}
\hline \multirow{2}{*}{ Location } & \multicolumn{3}{|c|}{ Transportation } \\
\cline { 2 - 4 } & On Land & In the Water & Total \\
\hline \hline Sea & 5 & 29 & 100.00 \\
\hline Inland Water & 14.71 & 85.29 & 23 \\
\hline$\%$ & 17 & 6 & 26.09 \\
\hline Total & 73.91 & 35 & 57 \\
\hline$\%$ & 22 & 61.40 & 100.00 \\
\hline
\end{tabular}

Note. Pearson chi-square $=20.2927, \operatorname{Pr}=0.000$.

Table 7. Location by the Stages of a Drowning Episode Depicted in Paintings with a Military or Combat Theme $\square$

\begin{tabular}{|c|c|c|c|}
\hline \multirow{2}{*}{ Location } & \multicolumn{3}{|c|}{ Drowning Stage } \\
\cline { 2 - 4 } & Immersion & Submersion & 15 \\
\hline \hline Sea & 19 & 44.12 & 100.00 \\
\hline$\%$ & 55.88 & 4 & 23 \\
\hline Inland Water & 19 & 17.39 & 100.00 \\
\hline$\%$ & 82.61 & 19 & 57 \\
\hline Total & 38 & 33.33 & 100.00 \\
\hline
\end{tabular}

Note. Pearson chi-square $=4.4098, \operatorname{Pr}=0.036$.

In Table 5, a statistically significant difference was noted between the bystander presence and the drowning stage $(\mathrm{p}=0.014)$. Specifically, in the presence of bystanders the casualties were more often immersed $(33,86.84 \%)$. On the other hand, submersion (even on the final stage of casualty's death) took place in almost the same frequency with the bystander's presence $(11,57.89 \%)$ or absence $(8,42.11 \%)$.
In Table 6, a statistically significant difference was noted between the location of drowning and the means of transportation $(\mathrm{p}<0.001)$. Specifically, people drowned more often at sea when they used aquatic transportation (e.g., ship, swimming for escape from enemies; 29, 85.29\%). Similarly, when the transportation was on land (e.g. horse, walking) then drowning took place in inland aquatic environment (e.g., lake, river; $17,73.91 \%$ ). 
Table 8. Water Depth by the Attempt to rescue a Drowning Casualty Depicted in Paintings with a Military or Combat Theme.

\begin{tabular}{|c|c|c|c|}
\hline \multirow{2}{*}{ Water Depth } & \multicolumn{3}{|c|}{ Rescue Attempt } \\
\cline { 2 - 4 } & No & Yes & Total \\
\hline \hline Deep & 39 & 3 & 72 \\
\hline$\%$ & 79.59 & 37.50 & 15 \\
\hline Standing Level & 10 & 5 & 26.32 \\
\hline$\%$ & 20.41 & 62.50 & 57 \\
\hline Total & 49 & 8 & 100.00 \\
\hline
\end{tabular}

Note. Pearson chi-square $=6.2837, \operatorname{Pr}=0.012$.

Table 9. Water Depth by the Transportation Means that were used during a Drowning Episode Depicted in Paintings with a Military or Combat Theme.

\begin{tabular}{|c|c|c|c|}
\hline \multirow{2}{*}{ Water Depth } & \multicolumn{3}{|c|}{ Transportation } \\
\cline { 2 - 4 } & On Land & In the Water & 73.68 \\
\hline \hline Deep & 9 & 33 & 15 \\
\hline Standing Level & 40.91 & 94.29 & 26.32 \\
\hline$\%$ & 13 & 2 & 57 \\
\hline Total & 59.09 & 5.71 & 100.00 \\
\hline$\%$ & 22 & 35 & 100.00 \\
\hline
\end{tabular}

Note. Pearson chi-square $=19.8485, \operatorname{Pr}=0.000$.

In Table 7, a statistically significant difference was noted between the location of drowning and the drowning stage $(p<0.001)$. Specifically, there was not any difference in the drowning stages when people drowned at sea (immersion: 19, 55.88\%; submersion: $15,44.12 \%$ ). On the other hand, people more often were immersed in inland aquatic environments (i.e., lakes, rivers; 19, 82.61\%).

In Table 8, a statistically significant difference was noted between the water depth and the rescue attempt $(\mathrm{p}=0.012)$. Specifically, in paintings depicting military activities that took place in deep water it was more likely that people would drown without being rescued $(39,79.59 \%)$. On the other hand, it was more often to see rescue attempts in shallow water $(5,62.5 \%)$.

In Table 9, a statistically significant difference was noted between the water depth and the means of transportation $(\mathrm{p}<0.001)$. Specifically, when the painting portrayed an aquatic transportation (e.g., ship or swimming to escape from enemies), not surprisingly the drowning occurred in deep water $(33,94.29 \%)$. On the other hand, when people were transported on land (e.g., walking or horses) they drowned more often in water that was standing level (13, $59.09 \%)$.
In Table 10, a statistically significant difference was noted between the casualty characteristics and the use of military weapons $(p=0.001)$. Specifically, when the drowning casualty was a military person then there was evidence of military weapons use $(24,72.73 \%)$. On the other hand, when the drowning casualties were civilians there was not any depiction of military weapons use $(17,70.83 \%)$.

In Table 11, a statistically significant difference was noted between the number of drowning casualties and the means of transportation $(\mathrm{p}=0.018)$. Specifically, when the painting depicted land transportation (i.e., horse or walking) then the casualty that occurred due to drowning was more often single $(11,61.11 \%)$. On the other hand, when the transportation was aquatic (i.e., ship or swimming) then the persons that drowned were more likely to be multiple (28, $71.79 \%)$.

\section{DISCUSSION}

This study aimed to reveal "hidden" messages by analyzing a sample of paintings that portrayed drowning episodes during military or combat situations. In the authors' opinion, this is possibly the first study that addressed this 
Table 10. Casualty Characteristics by the Use of Military Weapons During a Drowning Episode that was Depicted in Paintings with a Military or Combat Theme.

\begin{tabular}{|c|c|c|c|}
\hline \multirow{2}{*}{ Casualty Characteristics } & \multicolumn{3}{|c|}{ Military Weapons } \\
\cline { 2 - 4 } & Yes & No & 33 \\
\hline \hline Military & 24 & 9 & 100.00 \\
\hline$\%$ & 72.73 & 27.27 & 24 \\
\hline Civilians & 7 & 70.83 & 100.00 \\
\hline$\%$ & 29.17 & 26 & 57 \\
\hline Total & 31 & 45.61 & 100.00 \\
\hline
\end{tabular}

Note. Pearson chi-square $=10.6280, \operatorname{Pr}=0.001$.

Table 11. Casualty Number by the Transportation Means that were used During a Drowning Episode that was Depicted in Paintings with a Military or Combat Theme]

\begin{tabular}{|c|c|c|c|}
\hline \multirow{2}{*}{ Casualty Number } & \multicolumn{3}{|c|}{ Transportation } \\
\cline { 2 - 4 } & On Land & In the Water & 18 \\
\hline \hline One & 11 & 7 & 100.00 \\
\hline$\%$ & 61.11 & 38.89 & 39 \\
\hline Multiple & 11 & 28 & 100.00 \\
\hline Total & 28.21 & 31.79 & 57 \\
\hline$\%$ & 22 & 35 & 100.00 \\
\hline
\end{tabular}

Note. Pearson chi-square $=5.6269, \operatorname{Pr}=0.018$

research question, and therefore the possibility of comparing or contrasting the findings with previous published work was not possible. However, a discussion of some interesting findings needs to be done.

In terms of the rescuer and the casualty, we identified a few characteristics. Most paintings depicted drowning episodes in the absence of a rescuer. But in the very few cases that a rescuer was present, the rescuer was mostly an adult male. This was understandable though because at the battle field it was more likely that only adult men would witness an emergency and initiate a rescue to their fellow soldiers. On the other hand, we identified that most casualties were of adult males. Again, although at the battle the casualties may be of people of all age groups [11, 12], the fact that we identified mostly adult males presently is explained because a considerably high percentage of the depicted battles took place at sea in deep water or outside populated areas, where only armed men participated. Finally we also found that the victims who drowned together were of military as opposed to civilians. Again this happened because most aquatic emergencies were naval battles whereby only troopers could be involved.
In terms of place of occurrence, the paintings portrayed drowning episodes that took place more often at sea and less often in inland waters like lakes and rivers. It seems that the imagination of the artists was fueled by places where historical battles took place. Also, these drowning episodes took place more frequently in deep than in shallow water. This may have been on purpose to either add some degree of tragedy and desperation in the depicted casualties, or to correspond with a historical event. In addition, this was understandable to happen because a high number of paintings depicted battles at sea between ships.

In terms of circumstances of occurrence, we identified six variables worthy to be mentioned. Firstly, in only a few paintings a rescue attempt was portrayed. This may tell us that the artist was not interested in depicting an optimum aftermath of the drowning event. If no rescue attempt was made, it was probably due to the danger that it posed for the prospective rescuer; or that rescue services were not available in the specific period of history that was depicted in the painting. Secondly, paintings contained military people that carried weapons, thus weighting them down. This was common sense based on the sampling criteria of this study. Thirdly, the transportation means were either by 
horse or by walking on land, or by ship and thus by swimming in the water. This shows that most paintings made reference to an old period of history, where not only the means of transportation were primitive, but also the instrumentation and the rescue techniques were lacking. From the means of transportation, we may conclude that the lack of a higher percentage of rescue attempts was possibly due to lack of knowledge and therefore training in the early stages of human history. Forth, the casualties more often were portrayed to be immersed rather than submerged. This was possibly because it was more convenient for the artist to depict a casualty above the water surface or to increase the dramatic tone of desperation. Finally, drowning episodes took place in the presence of bystanders. They are presented in the paintings possibly as a factor of reality because a casualty was most probably surrounded by fellow soldiers and enemies or as fiction in order to add more drama (a person that drowns is helpless while others who are watching are unable or unwilling to help may be more tragic than someone who drowns and could not get help from anyone!).

The presence of a bystander during a drowning episode was more often apparent in military situations that took place during the day time (e.g., "North-Korean-art-l"). This is understandable for several reasons. First, although we were not able to classify the paintings into a chronological order and take into account the date that they presumably depicted, the majority of them portrayed an old period of time in which military technology, like "night vision" was nonexistent or rare. Secondly, another possible reason for seeing the painting during the day light could be because this was the only time that the bystanders (fellow soldiers or enemies) could indeed see and able to fight in a battle. The other reason of course could be that it was more convenient from a technical point of view for the artist to depict a daytime rather than a nighttime depiction. Thirdly, another reason maybe because this was how the artist was inspired by a historical battle or perceived a fictional combat situation.

When bystanders were present at a drowning scene, those involved in the military or combat situation carried military weapons. This is an interesting finding showing that, although those that drowned during military encounters were witnessed by their fellow warriors or the enemies, none could save them from drowning, because the rescuer's life would then be placed in danger. With modern water safety organizations claiming that the rescuer's safety comes first, we can appreciate how dangerous it could be to initiate a rescue if someone is not trained in lifesaving methods and is also threatened by an enemy at the same time. Especially in the cases when a warrior had fallen overboard during a naval battle, his rescue was almost impossible unless a rope or something could be thrown overboard.

When multiple casualties were portrayed as drowning during a military or combat operation, they were witnessed by bystanders. This is understandable because a high number of the sampled paintings depicted ships that were sinking and carrying many warriors who were still on board or who had fallen overboard (e.g., "The Jacquerie at Meaux, 1358”); all these drowning casualties were witnessed by their fellow soldiers or the enemy. Similarly, when drowning incidents that took place in inland water (lakes and rivers), some warriors drowned were witnessed either by their fellows or the enemy that were fighting nearby. However, the opposite happened in the absence of bystanders where the casualties drowned by themselves; they were in danger in the water on their own and unnoticed by anyone.

When bystanders were present, casualties were shown to be at the primary stage of drowning (i.e., immersion) in the water (e.g., "Death of Prince Joseph Poniatowski [17631813] in the Elstera River, 1813"). This may mean that they had just fallen into the water. Alternatively, we may assume that the artist wanted to portray the agony and desperation of those who fell into the water. In addition, this may be because it could not be easy for the artist to draw scenes in detail above (i.e., the battle) and below (i.e., the drowning) the water surface on the same painting. After all, the primary theme for all those paintings was war and the military engagements, and therefore, drowning was in most cases just an issue of secondary importance.

The location of drowning was related with the means of transportation that were used by those involved in a military or combat situation. Accordingly, military people drowned most often at sea when their ship sank or was submerged (e.g., "Persians drown at the Battle of Salamis", Fig. (1); "Battle of Gibraltar 1607”). Similarly emergency scenes at sea included warriors and civilians who tried to escape by swimming from their enemies (e.g., "Horatius Cocles escapes swimming in full armor", Fig. (2); "Scyllias and his daughter Hydna", Fig. 3). Also during military situations on land, the warriors that fought on foot or on their horses were portrayed to drown in lakes or rivers (e.g., "Flooding the Germans Out: Opening the Dykes Near Antwerp in the Environs of Temonde", "Death of Prince Joseph Poniatowski (1763-1813) in the Elstera River, 1813"). This finding was common sense as the means of transportation inevitably determined how far a person may go away from safety.

The casualties that drowned in inland aquatic environments were portrayed to be at the primary stage of drowning (i.e., immersion; e.g., "Troopers swim trying to escape from their enemies" in wall-painting found in the Mogao Cave 12, dating to the Tang Dynasty, ca. 700, Fig. 4). This could possibly be attributed to several reasons. The first reason may be because the artist wanted to show their agonizing fight to remain afloat, to give a more desperate tone on the painting. Secondly, it was because it could not have been technically possible to draw a person underwater. Finally, the artist may want to depict an accurate historical event that involved only an immersion before death by drowning took place.

The limited drowning rescues that were attempted in the examined sample of paintings were more often when the water depth was shallow. It was interesting to see that when drowning casualties needed mostly to be rescued in deep water, help was not available for them. On the other hand, when the water depth was shallow, and when they possibly needed less help, some fellows were rescued. This apparent paradox however is explained by the fact that during a military situation, it is very difficult for a prospective rescuer 


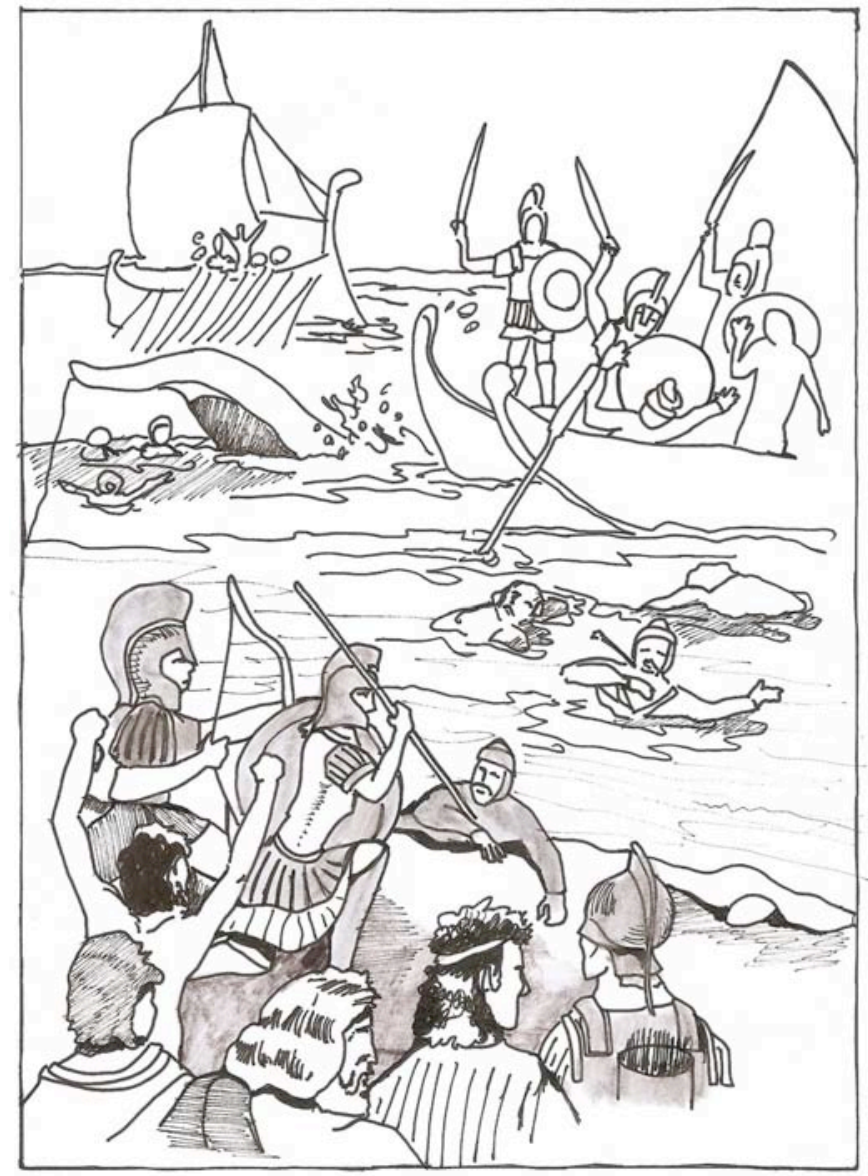

Fig. (1). Persians drown at the Battle of Salamis in ancient Greece.

Note. Drawn by Nikos Kouremenos. Copyright by Stathis Avramidis.

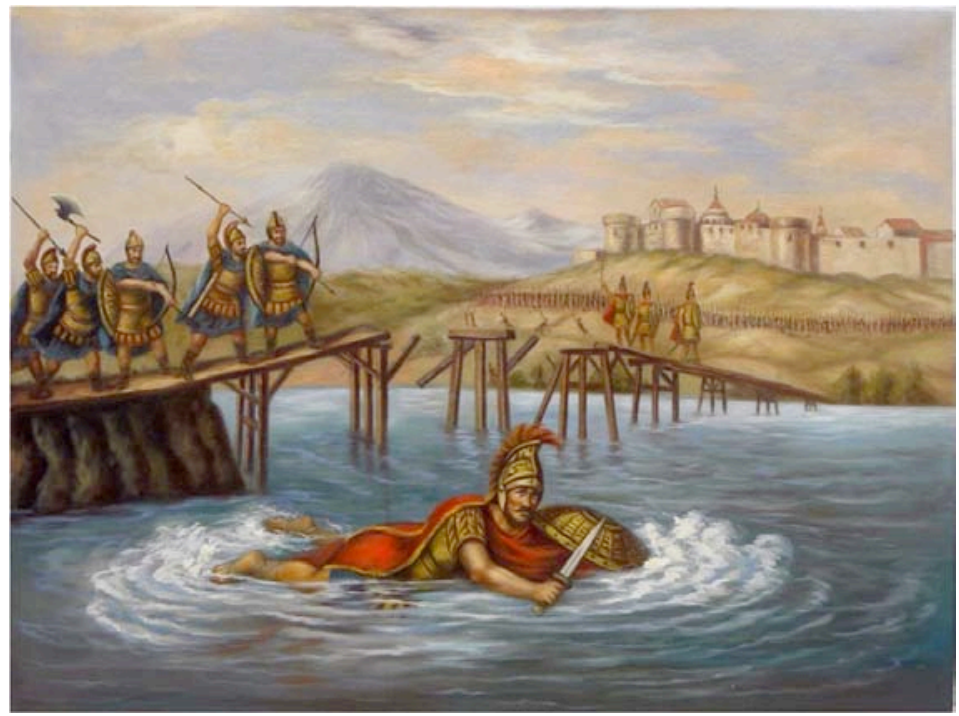

Fig. (2). Horatius Cocles escapes swimming in full armor. He avoids drowning because he was a competent swimmer.

Note: "The Roman legend of Horatius Colcles dates to the year 510 B.C. Rome had expelled the King imposed on it by the Etruscans and the Etruscan army was intent on teaching the upstart Romans a lesson. The historian Livy tells us that so rapid was the enemy advancing that there was no time to tear down the Sublican Bridge over the River Tiber and prevent them from retaking the city. One man, Horatius Cocles held off the Estruscans until the bridge was destroyed behind him. Then Cocles said, "Tiberinus, holy father, I pray thee to receive into thy propitious stream these arms and this thy warrior." So, fully armed, he leaped into the Tiber, and though many missiles fell over him he swam across the river in safety to his friends and immortality as the saviour of Rome." (p. 14) [14]. Colorized oil on Canvas reproduction of a German block engraving, 1810. Reproduction based on the original. Reproduced with permission by the International Swimming Hall of Fame. 


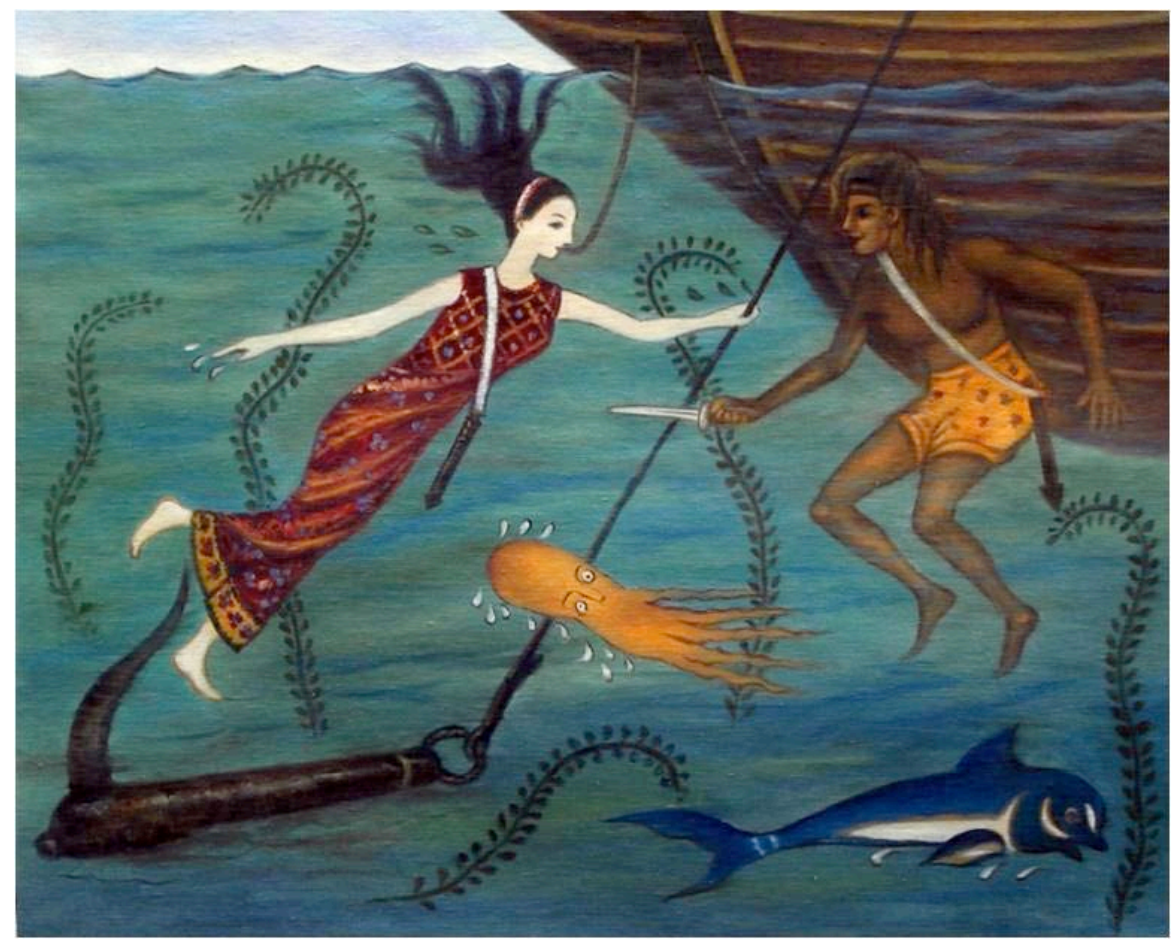

Fig. (3). Scyllias and his daughter Hydna with knifes and snorkels, cut the enemy moorings, escape by Persians and join the Greeks before the battle of Salamis.

Note: "In 480 B.C., while the Persian land forces were gathering at Thermopylae, Xerxes was making a bold move with his fleet. He dispatched a force of 200 ships to attack the Greeks by sea. On board one of the Persian ships were two Greeks, Scyllias and his daughter Hydna. Scyllias was an expert swimmer and diver who had taught his daughter to swim and dive well into the deepest parts of the sea since infancy. Earlier, they had been hired by Xerxes to recover treasure from a shipwreck. After recovering for the Persians what had been lost, father and daughter desired to return to Greece. But Xerxes wouldn't let them go, as they knew too much about the Persian plan of attack. One day, to avoid a violent storm, the fleet anchored in a safe harbour. The storm gave Scyllias and Hydna the opportunity to make their escape. But before doing so, they wanted repay the Persians for their hospitality. With knives in hand, the pair dove into the sea and silently swam among the boats, cutting their moorings. Tossed about by the wind and waves, the ships crashed together; some sank and many were crippled. The pair then swam 15 kilometers to safety in Greece, reportedly using snorkels visible in the painting, which enabled them to remain underwater to avoid detection. Later, the Greeks defeated the Persian fleet at the battle of Salamis, thus saving western civilization." (p. 18) [14]. Colorized oil on Canvas reproduction of wood block black and white print. Reproduction based on the original. Reproduced with permission by the International Swimming Hall of Fame.

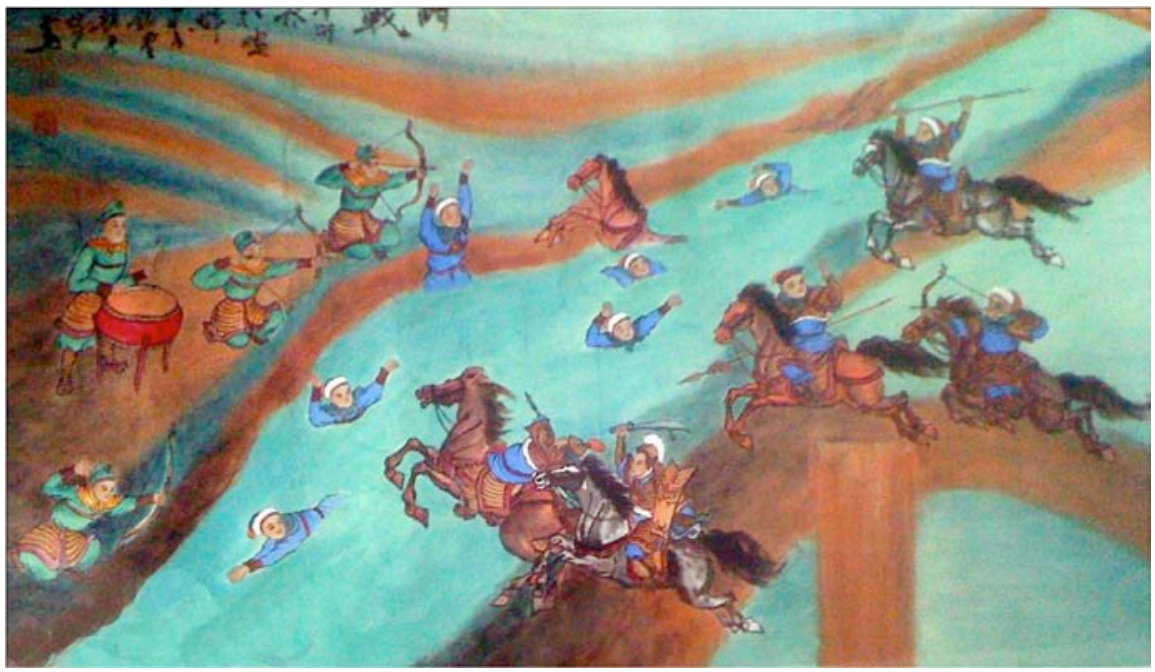

Fig. (4). Troopers swim trying to escape from their enemies while some of them drown.

Note: "A wall-painting found in the Mogao Cave 12, dating to the Tang Dynasty, ca. 700, shows the importance of swimming to military units. Whether thrown off horses, attacking or escaping, swimming was an important survival skill in the ancient world for soldiers." (p. 45) [14]. Ink and water color on silk paper. Wall-painting found in the Mogao Cave 12, dating to the Tang Dynasty, ca. 700. Reproduction based on the original. Reproduced with permission by the International Swimming Hall of Fame. 


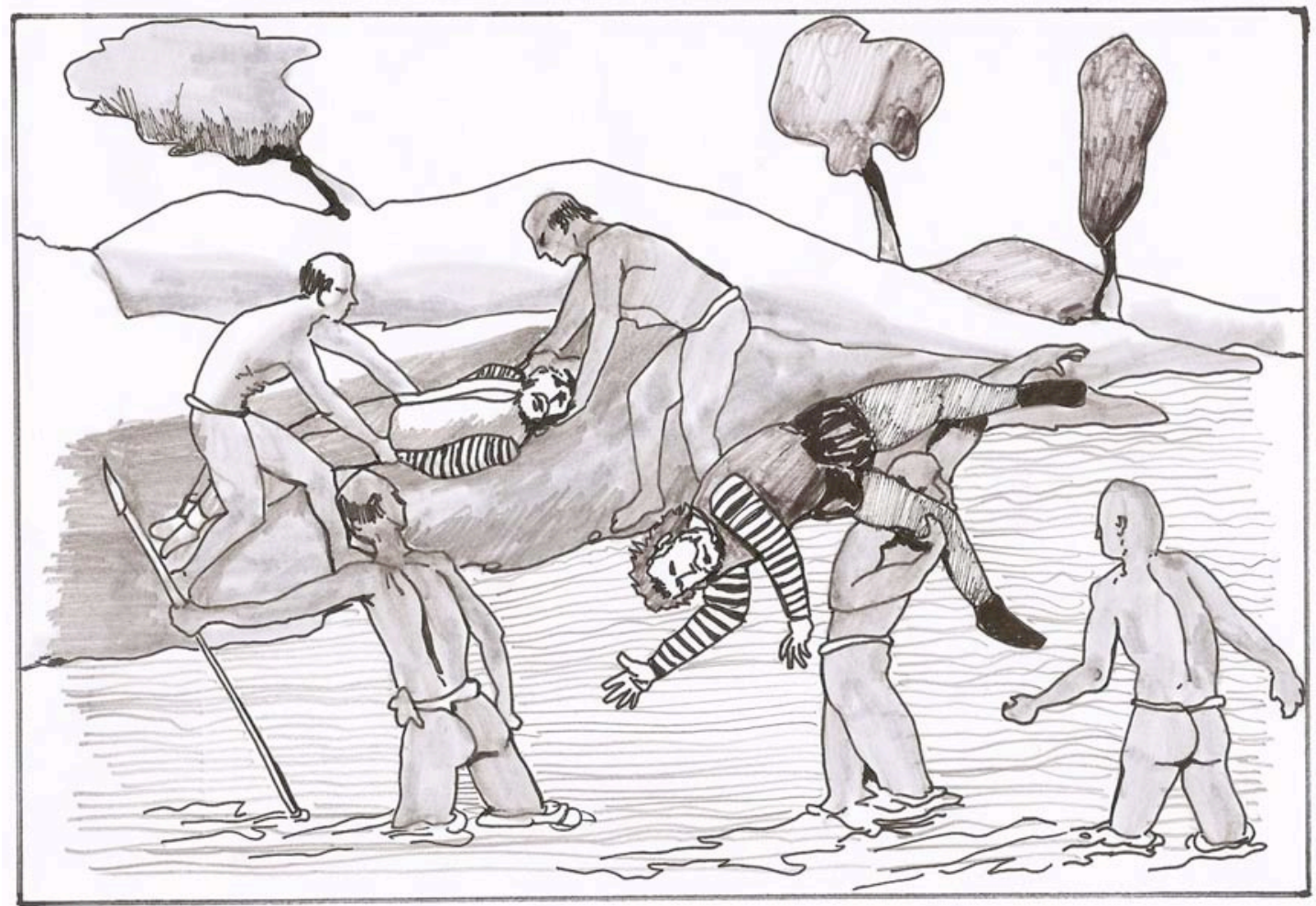

Fig. (5). South American Indians drowning Spaniards to see if they are immortal.

Note. Drawn by Nikos Kouremenos. Copyright by Stathis Avramidis.

to attempt to save a fellow warrior and also protect his life from the enemy's bullets or arrows. Therefore, it is understandable that artists did not often portray rescues for drowning that took place at sea where the water was deep. In addition, it may show that in the old days, the military armies had not possibly developed a rescue and/or first aid services that could possibly assist the wounded and those in danger in or around the water. Indeed, such innovations became common practice since the establishment of the Red Cross movement that aimed to help those in need by getting involved in combat situations applying their humanitarian mission.

The means of transportation were related with the water depth in which the drowning episode took place. Not surprisingly, when the warriors were engaged in a military situation at sea or even when they tried to escape from their enemies, this happened in deep water (e.g., "Battle of Zonchio 1499", "The Japanese Fleet Sinks Chinese Warships in the Battle of the Yellow Sea by Kobayashi Kiyochika"). This is understandable though because in the first case a naval battle may take place only in deep water whereas in the second case a warrior may escape from the enemy only by swimming underwater in depth that would be enough for hiding his body. On the other hand, those that fought on their feet or riding horses, often drowned in shallower water (e.g., "South American Indians drowning Spaniards to see if they are immortal", Fig. (5); "Allegory on the Turkish War-The Battle of Sissak, 1587').

During the drowning episode, weapons were carried on by military people as opposed to the unarmed civilians (e.g., "Raphael - The Battle at Pons Milvius"; "Three warriors swim across the Euphrates, probably escaping from the enemy", Fig. 6). This finding was not surprising as those that were engaged in a combat situation and drowned could either be military or civilians. The artists depicted the first armed and the second unarmed respectively. Except the apparent reason that arms were likely to be held by those that had a duty to fight, the artists may have sought here to present the desperation of the civilians that were helpless and inevitably drowned under the threat of the enemy weapons.

The number of drowning casualties depended on the means of transportation. When the fighters or civilians used a horse or walked at the battle field and experienced a drowning episode, they were most often in danger on their own (e.g., "Sargeant Kawasaki saves himself by swimming under a hail of bullets", Fig. (7); "Manuscript Illumination of a Drowning Viking, Possibly Olav Trygvason of Norway at the Battle of Svold"). This perhaps was because the artist wanted to give emphasis on a single drowning emergency. On the other hand, when people were transported by ship or swam, it was more likely that they would drown together with others (e.g., "Take up the Sword of Justice Poster by Bernard Partridge"). This was possibly due to the fact that the artistic depictions in this case portrayed mass combat events where more people were in danger at sea. Therefore, it seems that the sea accommodated a higher number of drowning casualties than land means of transportation.

Except everything that was discussed above based on our quantitative analysis, this study revealed the qualitative finding that these paintings depicted the skill of swimming in relation to drowning in an unfavorable way; troopers did not know swimming (or were too far from safety) and thus they 


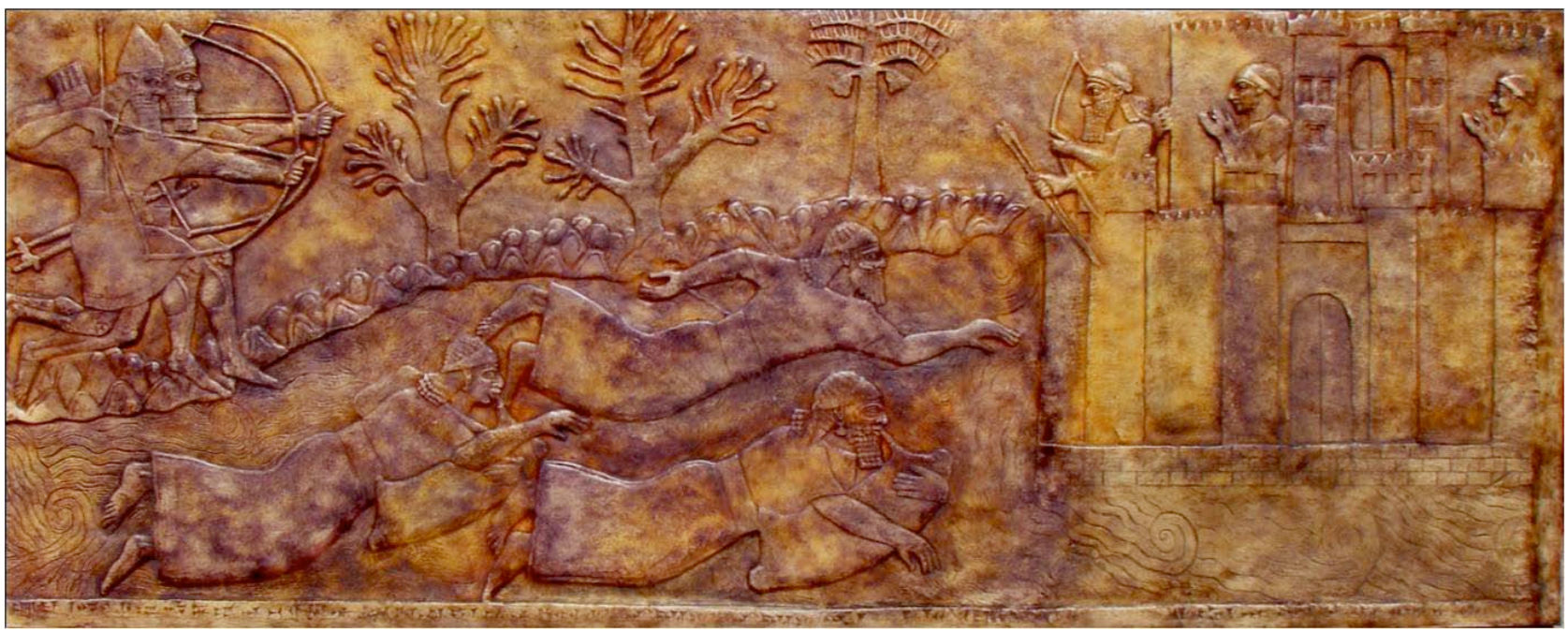

Fig. (6). Three warriors avoid drowning and being captured by the enemies swimming across the Euphrates. They use swimming strokes or ride on inflated skins retaining the aperture, through which the air is forced in their mouths.

Note: "In an Assyrian bas-relief from Tul Barsip (Kalat Nedjim, Syria), dating to 865 B.C. The original was a carved slab from King Ashurnasirpal II's throne room at Nimrud, Iraq, Assyrian, c865 BC. Three warriors are shown swimming across the Euphrates, probably escaping from the enemy. Two of them are riding on inflated skins, in the mode practiced into the early $20^{\text {th }}$ Century by the Arabs inhabiting the banks of the rivers of Assyria and Mesopotamia; except that in this bas-relief the swimmers are pictured as retaining the aperture, through which the air is forced in their mouths. The third swimmer, pierced by arrows discharged from the bows of the high-capped warriors kneeling on the bank, is swimming without the support of a skin against the current. There is little doubt that the Assyrian stroke depicted in this work of art was the "hand-over-hand" with the alternate stroke of the arms and legs." (p. 12) [14]. Assyrian bas-relief from Tul Barsip (Kalat Nedjim, Syria), dating to 865 B.C. The original was a carved slab from King Ashurnasirpal II's throne room at Nimrud, Iraq, Assyrian, c865 BC. Fiberglass reproduction from photographs of the original. Reproduced with permission by the International Swimming Hall of Fame.

drowned. Although swimming is regarded as an essential skill for everyone involved in an aquatic activity and especially for military personnel since antiquity [13], our sampled paintings of historical battles depicted most soldiers being drowning because they lacked swimming ability (e.g., "Battle of Salamis at 480 B.C."; "Battle of Pavia at 1525"; "Battle of Zonchio at 1499" etc) than surviving because they had swimming ability (see Figs. 2, 3, 6 and 7). This finding has three explanations. Firstly, it may be attributed to this study's method that used a criterion and convenient sample. The second explanation is that these paintings mirrored true historic events and therefore it was a matter of what really happened in the given battle (i.e., if the warrior died by drowning in reality, this was the only thing that could be depicted by the artist too and vice versa). The third explanation is that most paintings were drawn before the Enlightenment period (i.e., mid-18th century) where the water was perceived negatively due to the existence of potential dangers (e.g., sea monsters, the forces of nature etc. [14]). Indeed, in that period, the swimming was perceived as pessimistic and unfavorable. An author illustrated this accurately saying that "the activity of the swimmer is compared to the fate of the damned. He is not portrayed with attributes of strength, skill or survival; instead he is shown at the mercy of the sea, overwhelmed by its power and immensity, denied the means of reaching safety, and finally broken in despair. The image is that of a shipwrecked sailor who swims for a while in terror and in pain, only to be lost at the end." (p. 24, ([15]). It was only after the Enlightenment period that this perception was replaced by a positive one with the aquatic activities at a coastal area becoming positive, whereas the sea was linked with the creation of life [14] or other beneficial for the person aquatic activities (e.g., recreational swimming, underwater diving, fishing, bathing etc; [16-18]). This may possibly be another reason of why most of the paintings of our sample before the mid- $18^{\text {th }}$ century depicted drowning with a potentially fatal outcome whereas after this period we identified some paintings with troopers that avoided drowning.

Another qualitative finding was the relatively accurate depiction of a drowning person in most paintings. Although the universal features of the victim's agonizing effort to remain afloat were described just the last decades coining the term "instinctive drowning response" [19], the artists of the past drew the immersion victims in most cases with the head held above the water, the chin kept lifted to breath air and the arms laterally or forward extended. In the paintings that an unconscious person was depicted, the artwork represented again the reality with an even higher accuracy. It seems therefore that artists may have witnessed actual drowning cases and this knowledge helped them depict with a relative accuracy the immersion and submersion of a drowning person.

Almost all military victims of the assessed sample drowned fully dressed. Given that most of the sampled battles took place at sea or in inland water, it makes sense that troopers were in full armor to protect themselves from the enemy. But this happened for different reasons to troopers of different timeframes and civilizations. Specifically, Europeans of the medieval period were in difficulties in the water heavily armored while swimming was regarded as a fruitless struggle against the nature. In 


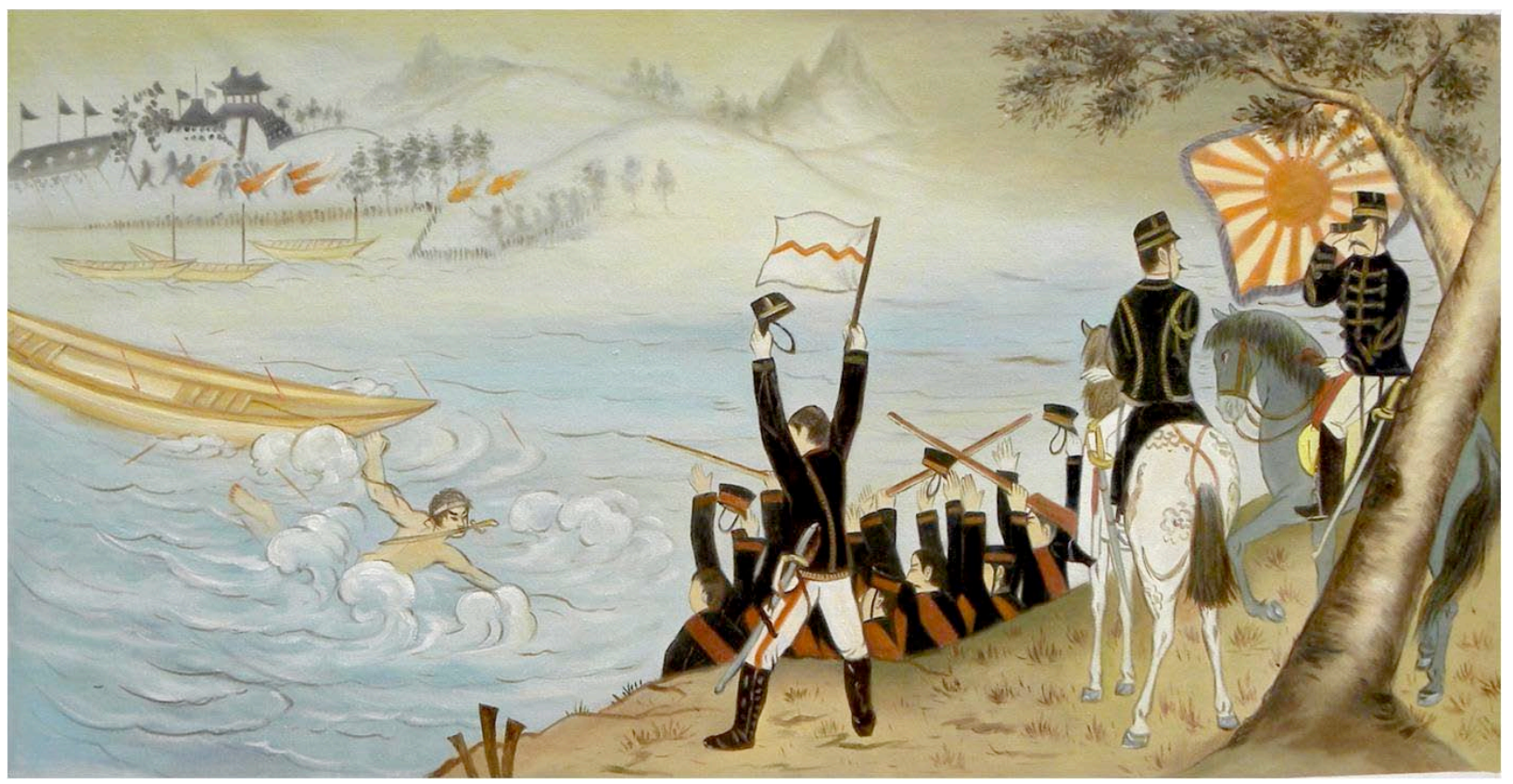

Fig. (7). Sargeant Kawasaki saves himself by swimming under a hail of bullets.

Note: "During the Sino-Japanese War of 1894, Sergeant Kawasaki led a recognizance team to scout the enemy positions and tried to steal boats from the enemy to cross the Tai-Tang River, in Korea. However, his unit was surprised by the advancing Chinese army and all of his comrades were killed. He managed to save himself by swimming across the Taidong River, under a hail of bullets, carrying a sword in his mouth and returning with a boat." (p. 49) [14]. Reproduction in oil on canvas from a Japanese woodblock "war-plate" print by Seishu. Reproduction based on the original. Reproduced with permission by the International Swimming Hall of Fame.

other words, they fought fully armored because they fell in the water unintentionally [20]. On the other hand, the opposite happened in Japan during the $15^{\text {th }}-16^{\text {th }}$ century and later at the Edo Shogunate period (1603-1867); piratical groups fought both on board a ship and in the water wearing their armor and helmet for protection because they had got related military training [21]. Collectively, all the above were depicted in the sampled paintings echoing the past, confirming that art should be considered, more or less, a part of history.

Finally, we revealed that some artists, who depicted limited cases of warriors that survived drowning because they were skillful swimmers, lacked a technical understanding of swimming. Precisely, the European images of our sample suggested that the artists did not know swimming nor had carefully observed a swimmer. For example, Horatius Cocles seems to crawl across the top of the water over the River Tiber (see Fig. 2) even though, by 1810 other European artists possessed the ability to accurately depict half submerged swimmers. Conversely, in other paintings, the warriors and the prisoners of war (see Figs. 3, 4, 6 and 7) suggest that the ancient European, Middle Eastern and Chinese and the early modern Japanese artists had actually studied swimmers or perhaps swam themselves. Given that artists were able to depict in precision the immersion and submersion stages of a drowning victim (as explained previously in this study by our quantitative analysis), it seems somehow surprising that they were unable to demonstrate a similar accuracy in their swimming related depictions. However, this understanding of the drowning attributes and lack of knowledge of the swimming technique from the artists' point of view may be explained by the fact that drowning is a much older phenomenon than the art of swimming in all civilizations. Therefore, it was more likely that artists may have seen someone drowning than swimming.

This study was subject to a number of limitations. First of all, its findings cannot be generalized because of the small sample and therefore it can give us only a glimpse of the messages that are revealed by the examined paintings. Secondly, only a few variables were able to be assessed in relation to drowning. Thirdly, we were unable to identify particular drowning patterns in military situations during specific periods of history (i.e., Ancient History, Middle Ages and Modern History), due to the chosen methodology and because each painting was represented by more than one date (i.e., the date of the military-drowning episode that it depicted if it portrayed a historic event, the date that the painting was created and the date that the original was reproduced by a secondary artist). Because of that, we could not assess the variable of the date quantitatively but only qualitatively. Fifth, due to the chosen methodology and the length constraints of the article, a description of all the sampled paintings was considered not possible to be included. Finally, although the paintings of military drowning produced in antiquity, medieval or early modern times, would have different meanings than the Christian meanings applied to Medieval, the Enlightenment and the Early Modern periods, the small size of our sample did not allow the framing of the drowning related variables into these clusters to achieve a broader understanding of the drowning and its antecedents. In other words, one of the study's strengths was also one of its weaknesses; its wide temporal and geographic scope undermined the formation of more definitive conclusions. 
Despite its numerous and important limitations, this study revealed some profound findings. First of all, it was obvious that art has played an essential and neglected role in preserving our historic and fictional heritage in the fields of drowning during military engagements. Secondly, it seems that such research may be a modest starting point that could serve as a "key" that would "unlock" our understanding of what artists wanted to tell us about drowning when we are watching their painting. Thirdly, it showed that although the use of swimming training as part of the military education curriculum was part of some civilizations through history, drowning was inevitable in some circumstances either because of the long distance a warrior had to cover to reach safety or because the dangers they had to avoid were too many. But in any case, the art of swimming was vital and this is why today it is considered as a basic requirement in contemporary military training. Finally, this study may help us establish the use of art as alternative means of education in lifesaving during wartime. For example, when water safety teachers and military officers know the existence of particular paintings and the messages that these reveal to their viewers, they could use them in their teaching classes as alternative means for attracting the attention of their pupils.

\section{CONCLUSIONS}

Collectively, this study came up with several profound and interesting conclusions. In specific terms, drowning casualties were portrayed to be most often military adult males who drowned at sea in deep water. They were often seen to be immersed, carrying weapons and were witnessed by bystanders. In the paintings that depicted a military or combat situation, the weapons were carried on by military people as opposed to the unarmed civilians and the drowning casualties were immersed in inland aquatic environments whereas the rescues were attempted in shallow water depth. In addition, bystanders more often witnessed episodes with multiple drowning casualties that immersed in the day time during warfare situations that involved weapons. The means of transportation of the casualties were related with the aquatic environment and the water depth as well as the number of the drowning casualties. Artists precisely depicted drowning immersion and submersion but not always accurately the body position in the water of warriors who were skillful in swimming. It also showed that those not knowing swimming were fated to die by drowning. In general terms, art has gifted us with a limited but interesting heritage of depictions that portrays drowning episodes at the battlefield and in combat situations. This wealth of information tells us how artists portrayed the moments of distress lived by warriors or civilians that had at the same time to survive from drowning and fight the enemy. A future study with a larger sample may facilitate a deeper examination of the "hidden" messages that art is revealing us each time we look at a painting hanged on the wall.

\section{CONFLICT OF INTEREST}

The authors confirm that this article content has no conflicts of interest.

\section{ACKNOWLEDGMENTS}

Acknowledgments should be given to Robert F. Dillon, BA, MAT, MS (Educator and Swim Coach, Founder/ Past President of a New Jersey Chapter of the United States Lifesaving Association and a Member of the International Swimming Hall of Fame) and Rebecca W. Robinson, MM, MS (Lioness Protects LLC) for editing advice prior to submission. Authors also wish to thank Bruce Wigo, J.D. (President/CEO of the International Swimming Hall of Fame) and cartoonist Nikos Kouremenos, BEd for the permission to reproduce and the drawing of the figures respectively. Finally, the authors wish to thank the two anonymous reviewers who spent time to provide constructive feedback during the first submission of the manuscript, making eventually this study more evaluative and meaningful.

\section{REFERENCES}

[1] Avramidis S. World Dt on Wwimming. Int J Aq Res Educ 2011; 3(5): 325-60.

[2] Avramidis S. Aquatic and Ofesaving lelated P essages that arise from Dt. In: Avramidis S, Ed. The IAHSFF Book 2012: Florida, USA: International Swimming Hall of Fame 2012: p. 179.

[3] Avramidis S. Art Depictions of Water Torture, Punishment and Homicide Drowning. In: Avramidis S, Ed. The IAHSFF Book 2012: Florida, USA: International Swimming Hall of Fame 2012: p. 184.

[4] Avramidis S. Artwork Depicting Historical, Religious and Fictional Drowning Incidents due to Flooding. In: Avramidis S, Ed. The IAHSFF Book 2012: Florida, USA: International Swimming Hall of Fame 2012: p. 189.

[5] Avramidis S. Artwork of Drownings and Rescues in Swimming and Aquatic Emergencies. In: Avramidis S, Ed. The IAHSFF Book 2012: Florida, USA: International Swimming Hall of Fame; 2012: p. 187.

[6] Avramidis S. Drowning and Rescue Related Artwork from Swimming and other Aquatic Activities with Religious Themes. In: Avramidis S, Ed. The IAHSFF Book 2012: Florida, USA: International Swimming Hall of Fame 2012: p. 181.

[7] Avramidis S. Drowning Incidents and Aquatic Rescues Depicted in Artwork with a Military Theme. In: Avramidis S, Ed. The IAHSFF Book 2012. Florida, USA: International Swimming Hall of Fame 2012: p. 190.

[8] Avramidis S. The History of Aquatic Safety. In: Avramidis S, Ed. The IAHSFF Book 2012: Florida, USA: International Swimming Hall of Fame 2012: p. 172

[9] Patton MQ. Qualitative Evaluation and Research Methods. $2^{\text {nd }}$ ed. Newbury Park: Sage 1990.

[10] Avramidis S, Butterly R, Llewellyn D. The 4W Model of drowning. Int J Aq Res Educ 2007; 1(3): 221-230.

[11] Borgman MA, Maegele M, Wade CE, Blackbourne LH, Spinella PC. Pediatric trauma BIG score: predicting mortality in children after military and civilian trauma. Pediatrics 2011; 127(4): e892897.

[12] Levy BS, Sidel VW. Adverse health consequences of the Iraq War. Lancet 2013; 381(9870): 949-958.

[13] Couch H. N. Swimming among the Greeks and Barbarians. Class J 1934; 29(8): 609-12.

[14] Corbin A. The Lure of the Sea: The Discovery of the Seaside in the Western World. California: University California Press 1994; 1750-1840

[15] Orme N. Early British Swimming, 55 B.C.-1719 A.D: with the first swimming treatise in English, 1595. England: University of Exeter Press 1983.

[16] Wigo B, Avramidis S. The "Art of Swimming". Famous Paintings from ISHOF's Collection of Swimming Art. Ft. Lauderdale, Florida, USA: International Swimming Hall of Fame Publishing (in press).

[17] Wigo B. A Race of Swimmers: Native American Swimming Skills Before and after the Arrival of the Europeans". In: Avramidis S, 
Ed. The IAHSFF Book; 2012: Florida, USA: International Swimming Hall of Fame 2012; pp. 138-162.

[18] Dawson K. Enslaved Underwater Divers in the Atlantic World. In: Avramidis S, Ed. The IAHSFF Book 2012: Florida, USA: International Swimming Hall of Fame 2012: pp. 101-9.

[19] Pia F. Observations on the drowning of non-swimmers. J Phys Educ 1974; 71(6): 164-6.
[20] Dawson K. Swimming, Surfing, and Underwater Diving in Atlantic Africa. In: Avramidis S, Ed. The IAHSFF Book 2012: Florida, USA: International Swimming Hall of Fame 2012: pp. 110-8.

[21] Matsui A, Goya T, Satake H. The History and Problem of Swimming Education in Japan. In: Avramidis S, Ed. The IAHSFF Book 2012: Florida, USA: International Swimming Hall of Fame; 2012; pp. 129-35.

Received: March 23, 2013

(C) Avramidis and Patrinos; Licensee Bentham Open.

This is an open access article licensed under the terms of the Creative Commons Attribution Non-Commercial License (http://creativecommons.org/licenses/ by-nc/3.0/) which permits unrestricted, non-commercial use, distribution and reproduction in any medium, provided the work is properly cited. 